\title{
Reconstructing the trophic history of the Black Sea shelf
}

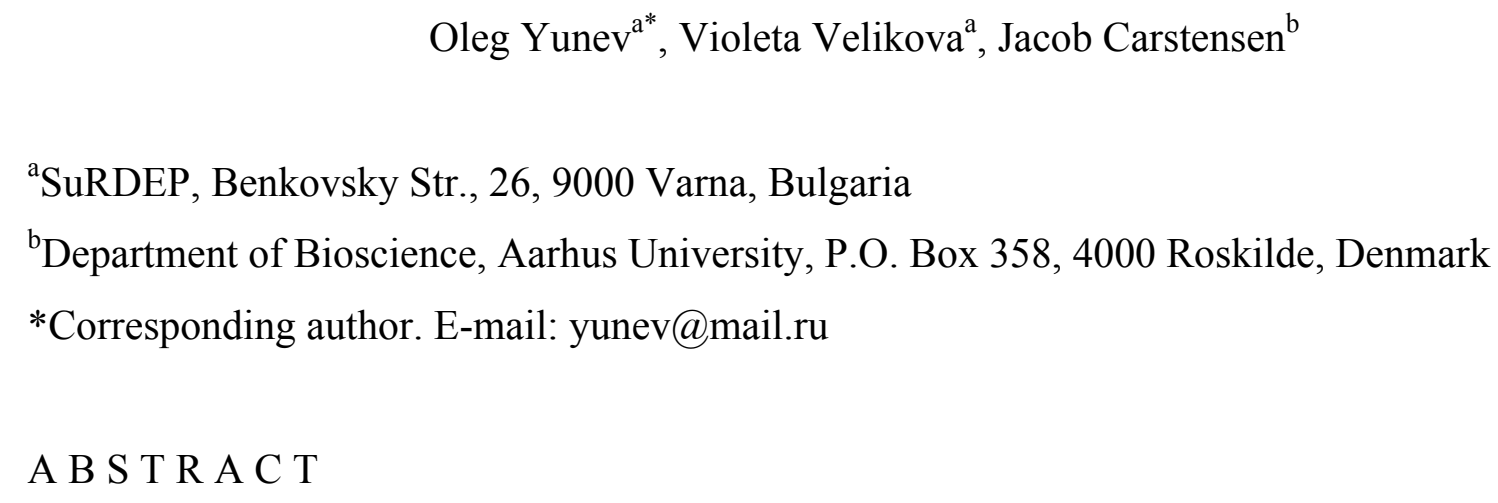

\section{A B S T R A C T}

In the last 50 years the Black Sea has undergone large changes driven by increasing anthropogenic pressures. We estimated the integrated annual primary production (APP) for different shelf regions during the early eutrophication phase (1963-1976) using chlorophyll $a$ and winter nitrate concentrations as proxy observations of primary production to describe its seasonal variation. For comparison, APP was estimated during the period when eutrophication peaked (1985-1992). In the early eutrophication period APP was estimated at 64-89 $\mathrm{g} \mathrm{C} \mathrm{m}^{-2} \mathrm{yr}^{-1}$ for most part of the shelf, except the shelf part influenced by the Danube River (the shallow waters off the Romanian and Bulgarian coasts) where APP was $\sim 126 \mathrm{~g} \mathrm{C} \mathrm{m}^{-2} \mathrm{yr}^{-1}$. In these two different shelf parts, APP increased to $138-190$ and 266-318 $\mathrm{g} \mathrm{C} \mathrm{m}^{-2} \mathrm{yr}^{-1}$ during the peak eutrophication period. These spatial differences are attributed to the large nutrient inputs from the Danube River. The APP estimates provide new insight into the eutrophication history of the Black Sea shelf, documenting stronger signs of eutrophiction than observed in other enclosed seas such as the Baltic Sea. Since the peak eutrophication period APP is estimated to have decreased by approximately $15-20 \%$.

Keywords: Annual primary production; Chlorophyll $a$; Nutrients; Early eutrophication phase; Eutrophication; Peak eutrophication period; Trophic status

\section{Introduction}

The Black Sea is considered one of the most susceptible to eutrophication among the large European enclosed seas (McQuatters-Gollop et al., 2009; Mee, 1992; Unluata et al., 1993). It has restricted exchange with the Mediterranean Sea, a relatively large catchment (five times the surface area of the Black Sea) and a high river runoff $\left(\sim 350 \mathrm{~km}^{3} \mathrm{yr}^{-1}\right)$. During the second half of the $20^{\text {th }}$ century, nutrient inputs from land to the entire Black Sea increased multifold (Mee, 1992). From the 1950 s - 1960s to the late 1980s - early 1990s annual discharges of dissolved inorganic nitrogen and 
phosphate from the Danube River rose by factors of 5 and 3, respectively (Cociasu et al., 1996; Konovalov et al., 1999; Zaitsev et al., 2006). These anthropogenically enhanced nutrient discharges resulted in significant increases in nutrients concentrations on the northwestern shelf (Bodeanu et al., 1998; Cociasu et al., 1996; Zaitsev et al., 2006; Yunev et al., 2007).

An observable immediate impact of elevated nutrient levels was the increase in frequency, intensity and spatial extent of phytoplankton blooms on the shelf, caused by abnormal proliferation of one or a few species (Bodeanu et al., 1998; Moncheva et al., 1995; Velikova, 1998; Velikova et al., 1999). In the 1980s, phytoplankton biomass on the shelf off the Danube River (May-September, 0-25 m) was approximately 8-9 times higher than in the 1950s and 1960s (Bodeanu et al., 1998; Yunev et al., 2009). Similarly, a tenfold increase in chlorophyll $a$ (Chl $a$ ) concentrations was observed for the same area: $0.66 \mathrm{mg} \mathrm{m}^{-3}$ in $1963,1.67 \mathrm{mg} \mathrm{m}^{-3}$ in 1976 and reaching $9.0 \mathrm{mg} \mathrm{m}^{-3}$ in 1980-1992 (Yunev et al., 2007). These trends were paralled by similar changes in phytoplankton, bio-optical and hydrochemical characteristics for the open Black Sea (Konovalov and Murray, 2001; Mikaelyan et al., 2013; Vedernikov and Demidov, 1993; Vladimirov et al., 1997; Yunev et al., 2002; 2005).

These consistent trends in nutrient inputs and concentrations of nutrients, Chl $a$, and phytoplankton biomass during the second half of the $20^{\text {th }}$ century would naturally lead to assume a synchronous increase in primary production (PP) (Nixon, 1995). For the open Black Sea, Yunev (2011) reported a doubling in annual primary production (APP) from about $63 \mathrm{C} \mathrm{m}^{2} \mathrm{yr}^{-1}$ in the 1960s to $135 \mathrm{~g} \mathrm{C} \mathrm{m}^{2} \mathrm{yr}^{-1}$ in the late 1980s - early 1990s. However, changes in PP over time in the shelf region remain an issue of discussion. For instance, Sorokin (2002) reported that primary production on the northwestern shelf had not increased from the 1960s to the late 1970s - 1980s. Other recent studies have similarly reported lack of positive trends in the Black Sea PP (Finenko et al., 2009) and no change in the trophic status of the sea for the last 50 years (Parhomenko and Krivenko, 2011).

Given the controversy over PP trends in the Black Sea shelf region, this paper has three main aims: (1) describe and compare seasonal variations of PP on the shelf in periods with relatively low (1963-1976) and high (1985-1992) nutrient inputs, (2) identify linkages between changing nutrient levels and APP, and (3) assess trends in trophic status for the whole Black Sea by combining APP values from the shelf with published data from the open Black Sea.

\section{Material and methods}

\subsection{Study area}


The Black Sea continental shelf is characterised by large spatial heterogeneity of biological and hydrochemical characteristics (Konovalov and Murray, 2001; Kopelevich et al., 2002; Yunev et al., 2007; Zaitsev et al., 2006). Hence, annual and long-term variability of Chl $a$ and PP were examined separately for six shelf regions (Fig.1): Regions 1, 2 and 3 - inner shelves with depths $<50 \mathrm{~m}$; Regions 4 and 5 - outer shelves with depths 50 - 200 m; Region 6 - shelf strip excluding the northwestern and western shelves with depths $<200 \mathrm{~m}$. These regions were designated on the basis of Black Sea characteristics (bathymetry, surface currents, surface phytoplankton biomass and surface Chl $a$ maps from satellite images, as well as riverine influence), which were described in detail by Yunev et al. (2002, 2005, 2007).

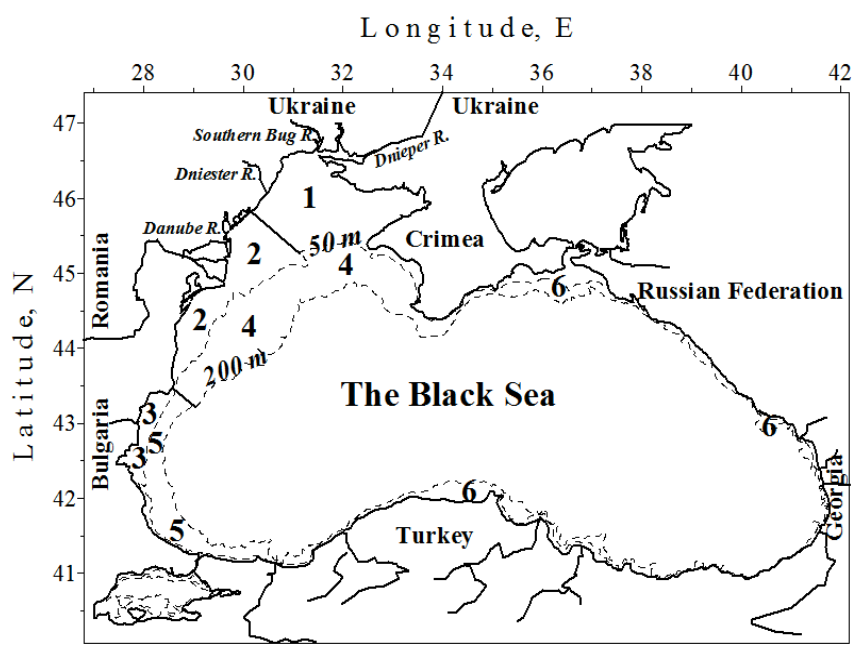

Fig. 1. Regions (1-6) of the Black Sea shelf used in the present study.

Riverine nutrient inputs largely determine primary production on the Black Sea shelf (Zaitsev et al., 2006). In this context, the designated regions have the following peculiarities. Region 1 is predominantly influenced by runoff from the rivers Dniester, Southern Bug and Dnieper (totalling $\sim 63 \mathrm{~km}^{3} / \mathrm{yr}$ ). These rivers discharge into the Black Sea through estuaries, which act as biogeochemical filters altering nutrient concentrations and their ratios before reaching the Black Sea shelf. Region 2 receives inputs from the Danube River $\left(\sim 210 \mathrm{~km}^{3} / \mathrm{yr}\right)$, which discharges into the sea through a large delta. Due to the dominating counterclockwise direction of the Black Sea Rim Current (Oguz et al., 1993), Region 3 is also moderately affected by the Danube River (Aubrey et al., 1996). The influence of the Danube River can even be traced to the deeper Region 5, whereas Region 4 is considered unaffected by Danube waters (Friedrich et al., 2002). Region 6 is a narrow shelf strip along the southern, eastern and northeastern coasts, which is not significantly influenced by rivers and anthropogenic nutrient pressure (Cociasu et al., 1996, Konovalov et al., 1999; Sur et al., 1996; Zaitsev et al., 2006). 


\subsection{Data sources}

Depth-integrated PP $\left({ }^{14} \mathrm{C}\right.$ method $)$ and surface $\mathrm{Chl} a$ data were obtained from the international database (TU-BS DB) compiled within the framework of the NATO TU Black Sea Project (TU Black Sea Data Base, 2003). Sampling and measurement methods underlying these data, and the comparability of data in the TU-BS DB, obtained with differing methodologies in the Black Sea countries, have already been described in the literature (Ivanov et al., 1998; Kopelevich et al., 2002; Stelmakh et al., 1998; Yilmaz et al., 1998; Yunev, 2011; Yunev et al., 2002; 2005; 2007; 2009). The TU-BS DB data were supplemented with PP and Chl $a$ data from the early literature (Bologa, 1977; Finenko, 1967; 1979; Skolka, 1968).

\subsection{Statistics}

Seasonal variations in Chl $a$ and PP were analyzed based on monthly arithmetic mean values, which have been shown to be approximately normal distributed for the Black Sea (Demidov, 2008; Vedernikov and Demidov, 2002; Yunev et al., 2002). Robust relationships between Chl $a$ and PP were established from a large data set (entire shelf area; 1980-1995) of simultaneous measurements using linear regressions for the log-transforms of both variables, stratified by seasons (spring, summer, autumn, and winter). Relationships for spring, autumn and winter observations were not different and consequently observations from these seasons were pooled. Estimated relationships for summer and the other seasons were compared by F-tests within the framework of general linear models. The estimated relationships were used to predict PP from $\mathrm{Chl} a$ observations, taking into account the bias correction (13.3\%) when back-transforming from the log-log regression.

\subsection{Methods of APP calculation}

So far, Black Sea APP values have been calculated using different variables (PP, Chl $a$ and satellite data) and aggregation approaches for different periods and regions (e.g. Finenko et al., 2009; Sorokin, 1962; 1964; 1982; Yunev, 2011). However, due to the scarcity of in situ data before the 1980s and unreliability of early satellite (CZCS) data (Kopelevich et al., 2002) seasonal variations in PP were not fully resolved to assess APP on the Black Sea shelf in the early phase of eutrophication. The only exception for this period was the Romanian inner shelf region (Region 2), where Chl $a$ measurements were carried out more regularly in 1963 and 1976 (Bologa, 1977; Skolka, 1968), allowing APP to be estimated. General relationships between PP and Chl $a$ were 
130 estimated on data collected in all regions of the Black Sea shelf in the period from 1980 to 1995, 131 and used to reconstruct PP monthly means from Chl $a$ observations in the early phase of 132 eutrophication in Region 2.

133 In order to estimate APP for other Black Sea shelf regions during the early phase of 134 eutrophication, we applied the approach by Elmgren (1989) for the Baltic Sea. Elmgren (1989) 135 estimated APP in the Baltic Sea above the natural background assuming spring primary production 136 to be proportional to the standing stock of winter-early spring inorganic nitrogen (Larsson, 1986), 137 and consequently the increase in spring PP was similar to the increase in winter-early spring nitrate 138 concentrations observed during the period with excessive nutrient inputs (Nehring et al., 1987). 139 Elmgren (1989) further scaled the increase in spring PP to other seasons using heuristically derived 140 factors, acknowledging that summer and autumn PP is mainly fueled from regenerated nutrients.

141 This approach could also be applied to the Black Sea shelves, since nutrient data from the early 142 phase of eutrophication were more abundant (see, e.g. Cociasu et al., 1996; Cociasu and Popa, 143 2005; Yunev et al., 2007; Zaitsev et al., 2006) and because PP is light limited in winter, similar to 144 the Baltic Sea.

145 Following Elmgren's approach, APP for the earliest data ( $\left.\mathrm{APP}_{\text {early }}\right)$ for Regions 1 and 3 were 146 calculated using data on: 1) the PP seasonal variation for the period 1985-1992, 2) increase factor 147 during spring $\left(\mathrm{IF}_{\mathrm{spr}}\right)$ based on the increase in winter-early spring nitrate concentrations and 3) IF 148 values for three other seasons: summer $\left(\mathrm{IF}_{\text {sum }}\right)$, autumn $\left(\mathrm{IF}_{\text {aut }}\right)$ and winter $\left(\mathrm{IF}_{\text {win }}\right)$. Unlike Elmgren 149 (1989), the proportionality between $\mathrm{IF}_{\mathrm{spr}}$ and the increase in winter-early spring nitrate 150 concentrations as well as the ratios of $\mathrm{IF}_{\text {sum }}, \mathrm{IF}_{\text {aut }}$ and $\mathrm{IF}_{\text {win }}$ values to $\mathrm{IF}_{\text {spr }}$ for the inner shelf of the 151 Black Sea western part were assessed using observations. In Region 2, seasonal IF values were 152 obtained by comparing the PP seasonal variations observed during the 1985-1992 period with the 153 earlier data. PP was reconstructed using data on $\mathrm{Chl} a$, available for this region in both periods 154 (Bologa, 1977; Skolka, 1968; TU Black Sea Data Base, 2003).

$155 \mathrm{APP}_{\text {early }}$ values for the outer shelf region of the western Black Sea (Region 4) and for the narrow 156 shelf $(0-200 \mathrm{~m})$ in the southern and eastern sea (Region 6) were estimated using data on APP for the 157 1985-1992 period ( APP $_{\text {peak }}$ ) combined with annual increase factor for PP (AIF) for the deep-open 158 Black Sea (Yunev, 2011) as there were no early data available for these regions. The AIF values 159 applied were assumed close to those from the open Black Sea, since both Regions 4 and 6 160 experienced insignificant nutrient inputs from land (Aubrey et al., 1996; Sur et al., 1996). Similarly, 161 the $\mathrm{APP}_{\text {early }}$ values for Region 5, which is influenced by Danube waters (Friedrich et al., 2002), 162 were estimated using the $\mathrm{APP}_{\text {peak }}$ value for this region combined with an AIF value, which was the 163 average of the values for the open sea and the neighbouring inner shelf (Region 3). 


\section{Results}

166

\subsection{Distribution of Chl $a$ and PP data among regions}

168

For the two periods of interest (early and peak eutrophication), Chl $a$ and PP data were 170 heterogeneously distributed over time and space (Table 1). In the early phase of eutrophication, PP

171 measurements were conducted for two months only (August and October) in Regions 1, 4, 5 and 6,

172 and Chl $a$ was measured in all months in Region 2. In contrast, during the peak eutrophication

173 period PP was generally measured throughout the year in all regions, although there were gaps for

174 some months. However, Chl $a$ measurements were carried out in all shelf regions and practically

175 throughout the year.

\section{Table 1}

178 Months and numbers of stations sampled for in situ $\mathrm{Chl} a$ and PP (conventional ${ }^{14} \mathrm{C}$ method)

179 measurements in different Black Sea shelf regions during the early (1963-1976) and peak (1985180 1992) periods of eutrophication. “-“ means no data available.

\begin{tabular}{|c|c|c|c|c|c|c|c|}
\hline \multirow{2}{*}{ Month } & \multirow{2}{*}{ Region } & \multicolumn{2}{|c|}{ Numbers of stations } & \multirow{2}{*}{ Month } & \multirow{2}{*}{ Region } & \multicolumn{2}{|c|}{ Numbers of stations } \\
\hline & & Chl $a$ & PP & & & Chl $a$ & PP \\
\hline \multicolumn{8}{|c|}{$1963-1976^{\mathrm{a}}$} \\
\hline January & 2 & 6 & - & August & 1 & - & 4 \\
\hline February & 2 & 5 & - & & 2 & 9 & - \\
\hline March & 2 & 6 & - & & 4 & - & 5 \\
\hline April & 2 & 8 & - & & 5 & - & 9 \\
\hline May & 2 & 11 & - & September & 2 & 15 & - \\
\hline June & 2 & 12 & - & October & 2 & 6 & - \\
\hline July & 2 & 10 & - & & 6 & - & 6 \\
\hline \multicolumn{8}{|c|}{$\begin{array}{l}\text { November } \\
1985-1992^{\mathrm{b}}\end{array}$} \\
\hline January & 1 & 3 & - & July & 1 & 10 & - \\
\hline & 2 & 8 & 3 & & 2 & 10 & 4 \\
\hline & 3 & 7 & - & & 3 & 15 & - \\
\hline & 4 & 12 & 4 & & 4 & 26 & 3 \\
\hline \multirow{5}{*}{ February } & 5 & 13 & 3 & & 5 & 19 & - \\
\hline & 6 & 3 & 3 & & 6 & 3 & - \\
\hline & 2 & 3 & - & August & 1 & 3 & 3 \\
\hline & 3 & 5 & - & & 2 & 3 & 3 \\
\hline & 4 & 3 & 3 & & 3 & 5 & - \\
\hline \multirow{6}{*}{ March } & 5 & 6 & - & & 4 & 3 & 3 \\
\hline & 6 & 4 & - & & 5 & 7 & - \\
\hline & 1 & 4 & 4 & & 6 & 5 & 4 \\
\hline & 2 & 3 & 3 & September & 1 & 9 & 5 \\
\hline & 3 & 6 & - & & 2 & 9 & 4 \\
\hline & 4 & 17 & 4 & & 3 & 4 & - \\
\hline
\end{tabular}




\begin{tabular}{cccccccc}
\multirow{3}{*}{ April } & 6 & 8 & - & & 4 & 45 & 9 \\
& 1 & 6 & 3 & & 5 & 6 & - \\
& 2 & 5 & - & 6 & 6 & 3 \\
& 3 & 3 & - & October & 1 & 5 & 3 \\
& 4 & 7 & - & & 2 & 4 & 4 \\
\multirow{4}{*}{ May } & 5 & 17 & - & 3 & 8 & 8 \\
& 6 & 3 & - & & 3 & 3 & 3 \\
& 1 & 4 & - & & 5 & 3 & 4 \\
\multirow{3}{*}{ June } & 2 & 5 & - & & 6 & 17 & - \\
& 3 & 11 & 4 & November & 1 & 4 & - \\
& 5 & 11 & 4 & & 2 & 5 & - \\
& 1 & 5 & - & & 3 & 4 & 5 \\
& 2 & 3 & - & & 4 & 14 & - \\
& 3 & 15 & 5 & & 5 & 5 & 7 \\
& 4 & 11 & 4 & & 6 & 8 & 3 \\
\end{tabular}

9

$-$

$$
3
$$

4

8$$
3
$$

4

-

$-$

6

$-$

$-$ 4

7

${ }^{\mathrm{a}}$ Metadata for the period were taken from Bologa (1977), Skolka (1968) and Sorokin (1962).

${ }^{\mathrm{b}}$ Metadata for the period were taken from the TU Black Sea Data Base (2003).

APP could not be estimated directly by simple integration over all months in any region due to the general lack of in situ PP data (Table 1). Consequently, the more abundant Chl $a$ data were used to reconstruct seasonal variations in PP by filling the gaps, which allowed for estimating APP. Given the data availability, PP was either measured or reconstructed from Chl $a$ in all regions during the peak eutrophication period and for Region 2 in the early phase of eutrophication.

\subsection{Reconstructing PP seasonal patterns during peak eutrophication period}

Chl $a$ seasonal patterns differed broadly among regions during the peak eutrophication period (Fig. 2). Region 1 experienced the same Chl $a$ level in January and March as between August and November $\left(\sim 1.5 \mathrm{mg} \mathrm{m}^{-3}\right)$. In three shelf regions off the Romanian and Bulgarian coasts (Regions 2, 3 and 5), the influence of Danube River was clearly visible. Peaks of Chl $a$ were observed in May $\left(10.7 \pm 4.8,4.4 \pm 2.2\right.$ and $3.4 \pm 1.5 \mathrm{mg} \mathrm{m}^{-3}$ for the three regions), consistent with the months of maximum discharge from the Danube River (April/May, Humborg, 1997). It should also be noted that the monthly means of $\mathrm{Chl} a$ were generally larger in these regions influenced by the Danube River than in Region 1 influenced by the Dnieper, Dniester and Southern Bug rivers. In Regions 4 and 6 the seasonal dynamics of Chl $a$ were characterized by a major peak during the winter-early spring blooms, smaller peak in autumn and overall low Chl $a$ concentrations in summer, similar to the seasonal patterns of the open sea (Yunev et al., 2002). 


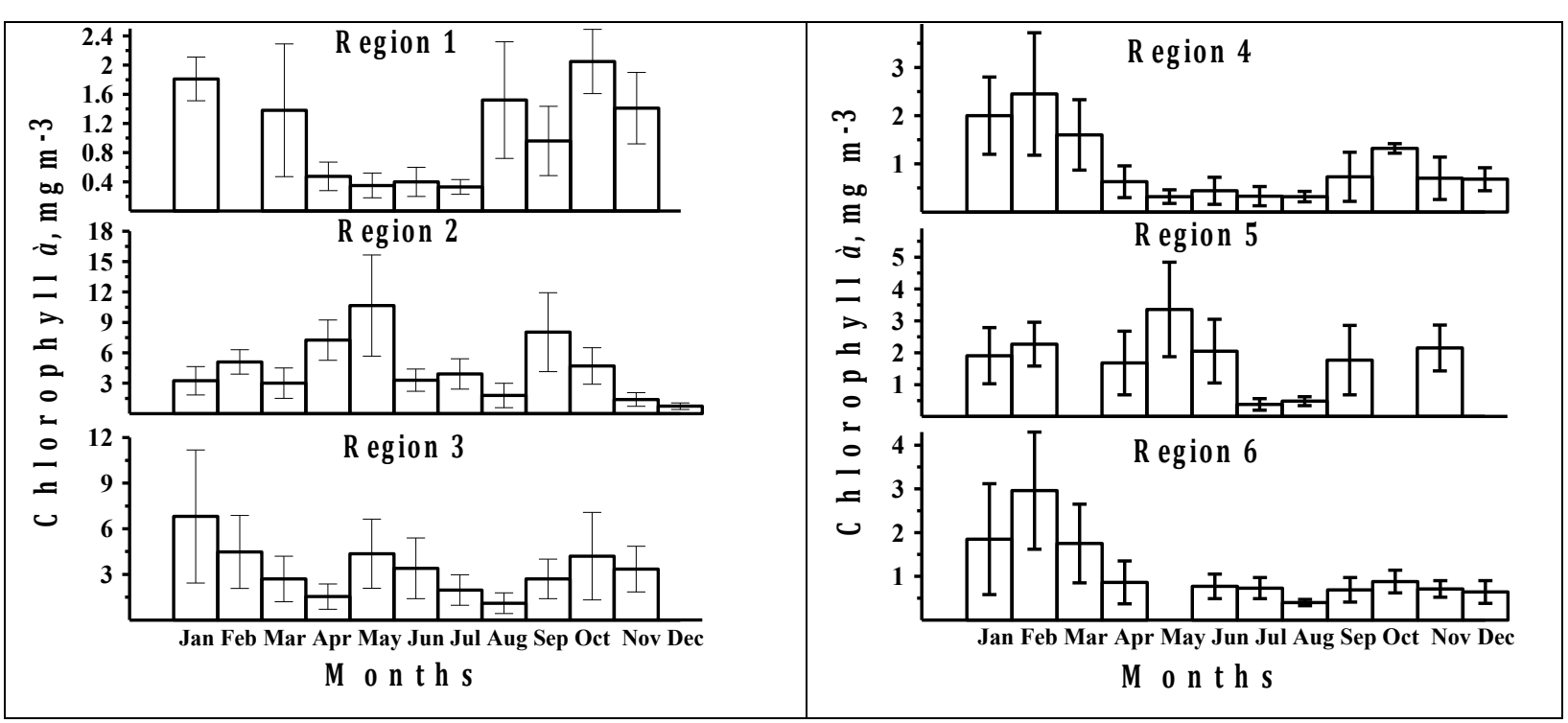

Fig. 2. Seasonal variation of $\mathrm{Chl} a$ in different Black Sea shelf regions during the period of peak eutrophication (1985 - 1992). Values are shown as the mean Chl $a \pm 1$ standard deviation.

PP correlated strongly with Chl $a$, but the relationship varied between summer and other seasons (Fig. 3). The slopes of the two regressions were not significantly different $\left(\mathrm{F}_{1,128}=0.19\right.$; $\mathrm{P}=0.6654$ ), whereas the intercept for summer months (June-August) was significantly higher $\left(\mathrm{F}_{1,128}=44.84 ; \mathrm{P}<0.0001\right)$ than for other seasons (September-May), yielding a generally higher PP per unit of Chl a. Measured and predicted PP were also in good agreement, justifying the reconstruction approach (Fig. 4). The predicted values could not fully reproduce the lowest and highest PP measurements, since the regressions describe the mean relationships and deviations from these are considered random fluctuations. Thus, the predicted values are suitable for describing monthly means but less suitable for describing specific PP measurements.

The reconstructed values largely reproduced the annual variations of measured PP in all regions (Fig. 5). Although there were obvious differences for certain months in some regions, the effect of these differences became smaller when integrating values across months. For example, in Region 4 PP integrated over the 10 months with measurements resulted in 116 and $120 \mathrm{~g} \mathrm{C} \mathrm{m}^{-2}$ using the measured and predicted values, respectively. APP was estimated to vary from $138 \mathrm{~g} \mathrm{C} \mathrm{m}^{-2}$ in Region 4 to $318 \mathrm{~g} \mathrm{C} \mathrm{m}^{-2}$ in Region 2 (Table 2) when reconstructed monthly means were used to fill the gaps without PP measurements in Fig. 5. 

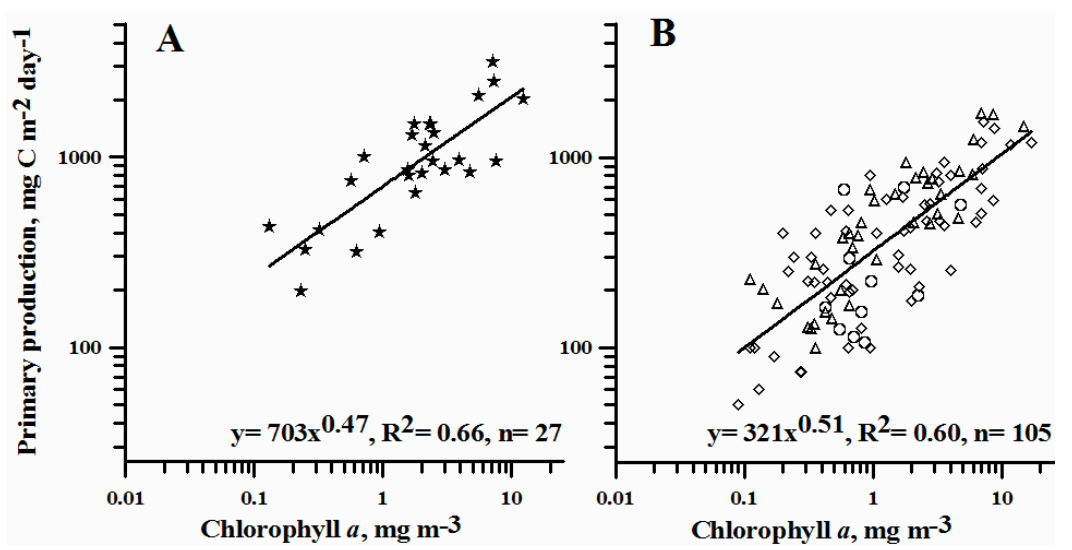

225 Fig. 3. Relationships between PP and Chl $a$ over the entire Black Sea shelf (1980-1995): A) summer $(\star)$ and B) autumn $(\diamond)$, winter $(\bigcirc)$ and spring $(\triangle)$.

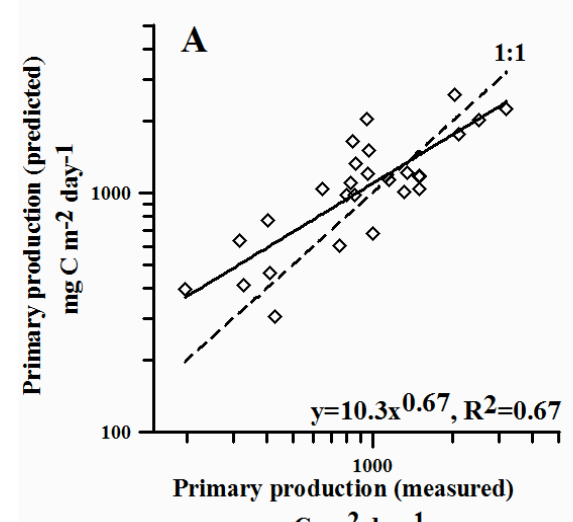
$\mathrm{mg} \mathrm{C} \mathrm{m}$ may $^{-1}$

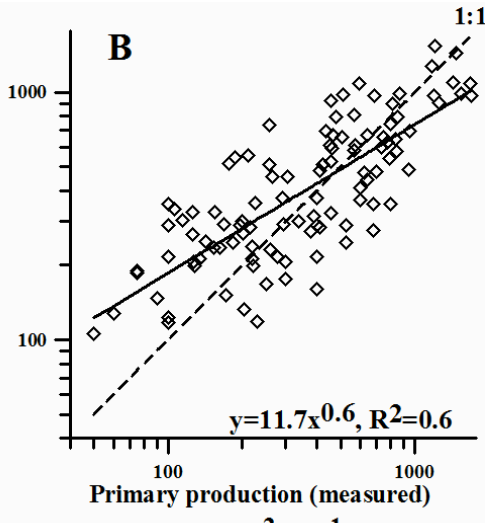

$\mathrm{mg} \mathrm{C} \mathrm{m}$ may $^{-1}$

Fig. 4. Comparison of predicted and measured PP values in summer (A) and autumn, winter and
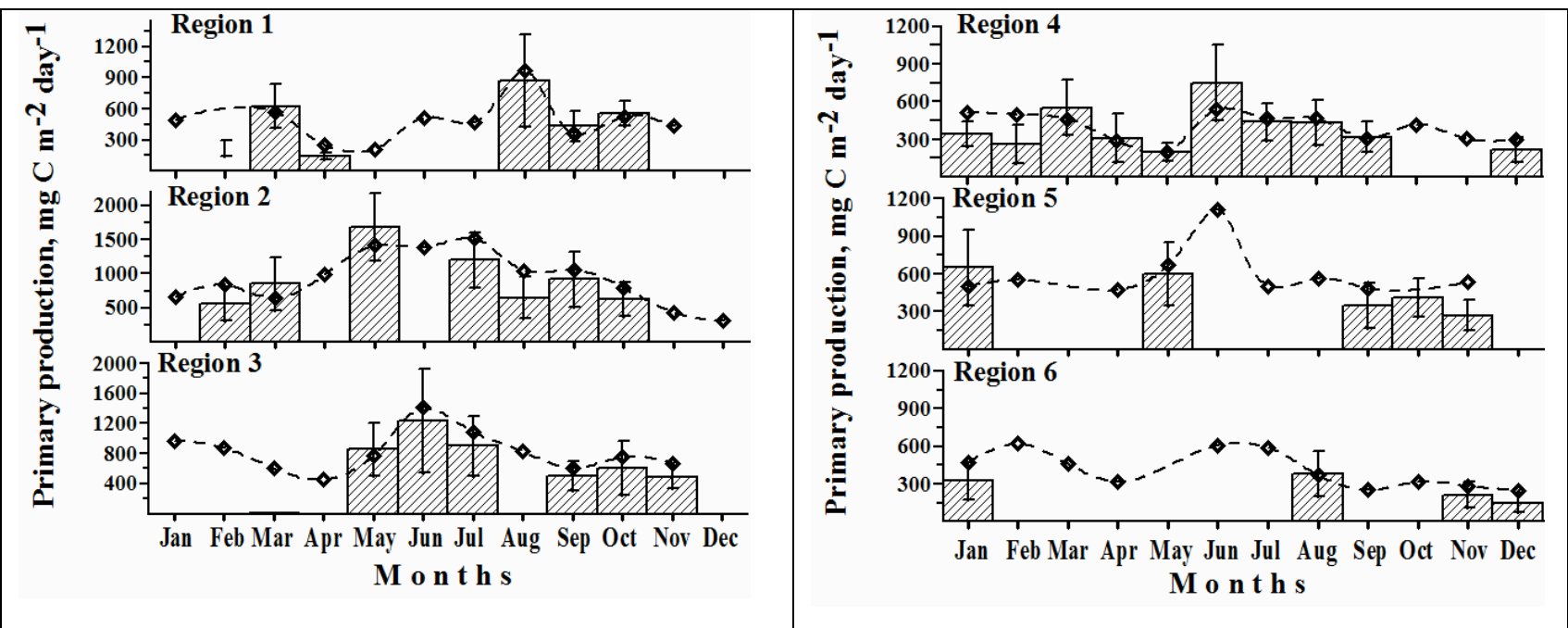

232 Fig. 5 Monthly means of measured (bars) and predicted (symbols in broken line) PP in the Black

233 Sea shelf regions for the peak eutrophication period (1985-1992). Measured values are shown as the mean $\mathrm{PP} \pm 1$ standard deviation. 
Table 2

236 Annual integrated primary production $\left(\mathrm{APP}_{\text {peak }}\right)$ in the different shelf regions during the peak 237 eutrophication period (1985-1992).

\begin{tabular}{lcccccc}
\hline Shelf regions & 1 & 2 & 3 & 4 & 5 & 6 \\
\hline $\mathrm{APP}_{\text {peak }}, \mathrm{g} \mathrm{C} \mathrm{m}^{-2} \mathrm{yr}^{-1}$ & 164 & 318 & 266 & 138 & 190 & 148 \\
\hline
\end{tabular}

\subsection{Reconstructing PP seasonal patterns during early eutrophication period}

Chl $a$ was measured in all months (except December) during the early eutrophication period only in Region 2 (Table 1) and therefore, in this region, monthly PP values could be predicted from the monthly Chl $a$ values (Fig. 6) using the season-specific relationships (Fig. 3). APP was estimated by summing up all monthly PP values, yielding $127 \mathrm{~g} \mathrm{C} \mathrm{m}^{-2}$ for the early eutrophication phase, whereas PP aggregated over the four seasons varied from 24 to $48 \mathrm{~g} \mathrm{C} \mathrm{m}^{-2}$ (Table 3 ).

APP in Region 2 increased by factor of 2.5 from the early eutrophication period (1963-1976) to the peak eutrophication period (1985-1992) (Table 3). The increase was largest in spring and decreased towards winter, as also indicated by $\mathrm{R}$. The increase of PP in spring (IF $\mathrm{spr}_{\text {r }}$ was comparable to the observed increase in winter-early spring nitrate concentrations over time (4.08; Yunev et al. 2011), supporting the use of changes in winter-early spring nitrate concentrations to infer changes in spring PP.

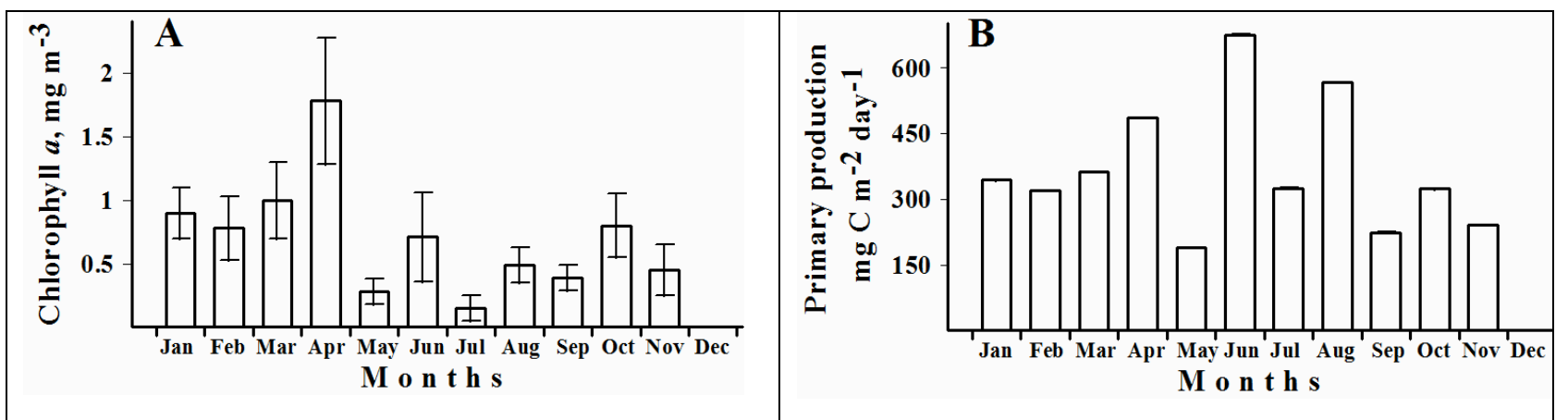

Fig. 6. Region 2 during the early eutrophication period: A) average monthly Chl $a$ (mean \pm 1 standard deviation) in the surface layer according to in situ data (Bologa, 1977; Skolka, 1968) and B) predicted average monthly primary production using the relationships in Fig. 3. 
Table 3

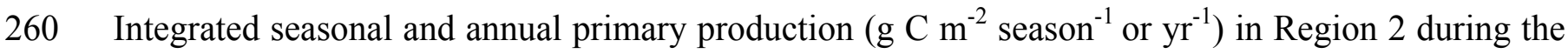
261 early $\left(\mathrm{PP}_{\text {early }}\right)$ and peak $\left(\mathrm{PP}_{\text {peak }}\right)$ eutrophication periods with increase factors (IF) for primary 262 production and the ratios $(\mathrm{R})$ of $\mathrm{IF}_{\text {sum }}, \mathrm{IF}_{\text {aut }}$ and $\mathrm{IF}_{\text {win }}$ to $\mathrm{IF}_{\mathrm{spr}}$.

\begin{tabular}{lcccc}
\hline Season & $\mathrm{PP}_{\text {early }}$ & $\mathrm{PP}_{\text {peak }}$ & $\mathrm{IF}$ & $\mathrm{R}$ \\
\hline Spring & 30 & 115 & 3.83 & - \\
Summer & 48 & 98 & 2.04 & 0.53 \\
Autumn & 24 & 60 & 2.50 & 0.72 \\
Winter & 25 & 45 & 1.80 & 0.47 \\
Annual & 127 & 318 & 2.50 & - \\
\hline
\end{tabular}

263

In order to calculate APP values for the early eutrophication period for Regions 1 and 3 we assumed proportionality between $\mathrm{IF}_{\mathrm{spr}}$ and the increase in winter-early spring nitrate concentrations in these inner shelf regions of the western Black Sea as well, and used the $\mathrm{R}$ values obtained for Region 2 (Table 3 ) to estimate IF values for the other seasons. IF $_{\text {spr }}$ values were set to published increases in winter-spring nitrate concentrations: 4.12 for Region 1 (Zaitsev et al., 2006) and 3.60

269 for Region 3 (Rozhdestwenskiy, 1990). Scaling these $\mathrm{IF}_{\mathrm{spr}}$ values with $\mathrm{R}$ (Table 3) produced 270 increase factors for summer, autumn and winter ranging from 1.94 to 2.68 in Region 1 and from

2711.69 to 2.34 in Region 3 (Table 4). Seasonal and annual integrated PP values were compiled for the 272 two regions, producing $\mathrm{APP}_{\text {early }}$ estimates of 67 and $125 \mathrm{~g} \mathrm{C} \mathrm{m}^{-2} \mathrm{yr}^{-1}$, respectively.

\section{Table 4}

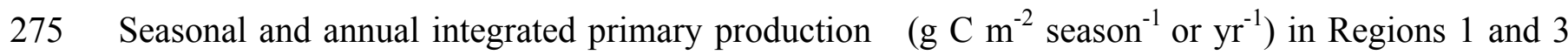
276 during the early $\left(\mathrm{PP}_{\text {early }}\right)$ and peak $\left(\mathrm{PP}_{\text {peak }}\right)$ eutrophication periods with the increase factors (IF) used 277 for hincasting PP during the early eutrophication period.

\begin{tabular}{lcccccc}
\hline \multirow{2}{*}{ Season } & \multicolumn{3}{c}{ Region 1 } & \multicolumn{3}{c}{ Region 3 } \\
\cline { 2 - 7 } & $\mathrm{PP}_{\text {peak }}$ & IF & $\mathrm{PP}_{\text {early }}$ & $\mathrm{PP}_{\text {peak }}$ & IF & $\mathrm{PP}_{\text {early }}$ \\
\hline Spring & 30 & 4.12 & 7 & 59 & 3.60 & 16 \\
Summer & 57 & 2.18 & 26 & 91 & 1.91 & 48 \\
Autumn & 43 & 2.68 & 16 & 48 & 2.34 & 21 \\
Winter & 34 & 1.94 & 18 & 68 & 1.69 & 40 \\
Annual & 164 & 2.45 & 67 & 266 & 2.13 & 125 \\
\hline
\end{tabular}




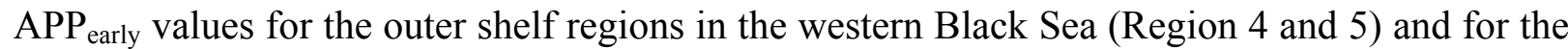
narrow shelf in the southern and eastern sea (Region 6) were estimated by scaling APP ${ }_{\text {peak }}$ values for these regions (Table 2) with AIF $=2.14$ for Region 4 and 6 (same value as for the open Black Sea; Yunev, 2011) and AIF $=2.13$ for Region 5 (average of the AIF values for the open Black Sea and the neighbouring inner shelf Region 3; Table 4). Hence, the resulting APP early values in Regions 4,5 and 6 were 64,89 and $69 \mathrm{~g} \mathrm{C} \mathrm{m}^{-2} \mathrm{yr}^{-1}$, respectively.

\subsection{Long-term changes in Black Sea APP values}

Summarizing the changes in APP over time suggests that all shelf regions as well as the open Black Sea have been exposed to eutrophication, with increases in annual primary production by factors between 2 and 2.5 (Fig. 7). The early phase of eutrophication was characterized by relatively low $\mathrm{APP}_{\text {early }}\left(<100 \mathrm{~g} \mathrm{C} \mathrm{m}^{-2} \mathrm{yr}^{-1}\right)$ in most shelf regions and in the open Black Sea. Higher APP early values were obtained for the inner shelf areas directly influenced by the Danube River (127 and 125 $\mathrm{g} \mathrm{C} \mathrm{m}^{-2} \mathrm{yr}^{-1}$ for Regions 2 and 3, respectively). These two regions also experienced the highest $\mathrm{APP}_{\text {peak }}$ values (318 $\mathrm{g} \mathrm{C} \mathrm{m}^{-2} \mathrm{yr}^{-1}$ in Region 2 and $266 \mathrm{~g} \mathrm{C} \mathrm{m}^{-2} \mathrm{yr}^{-1}$ in Region 3). APP increased approximately 2.5 times in the northwestern shelves (Regions 1 and 2), as these regions were more strongly influenced by large rivers delivering increasing nutrient inputs. In other areas, including the open sea, APP approximately doubled. APP levels over time in all shelf regions, except the most productive areas (Regions 2 and 3), were close to those of the open Black Sea. Integrating the shelf regions and the open Black Sea by the area they represent resulted in an overall increase in APP for the Black Sea, as a whole, from 68 to $148 \mathrm{~g} \mathrm{C} \mathrm{m}^{-2} \mathrm{yr}^{-1}$.

Longitude, $\mathrm{E}$

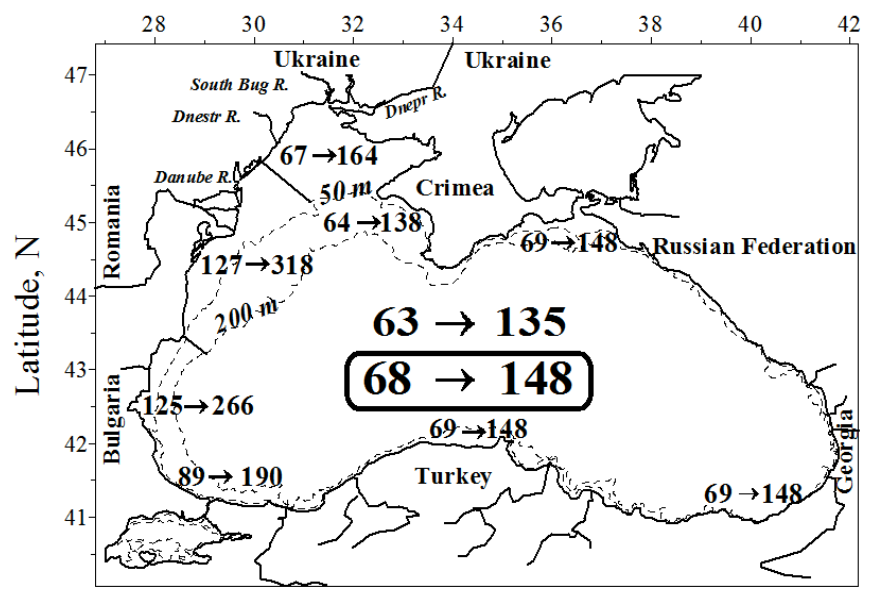

Fig. 7. Changes in APP $\left(\mathrm{g} \mathrm{C} \mathrm{m}^{-2} \mathrm{yr}^{-1}\right)$ for different shelf regions as well as the open Black Sea (Yunev, 2011) from the early (1963-1976) to the peak (1985-1992) eutrophication periods. The change in APP for the entire Black Sea is shown in the center frame. 


\section{Discussion}

306

\subsection{APP estimation methods}

308

The first PP measurements with the ${ }^{14} \mathrm{C}$ method on the Black Sea shelf were carried out (together with measurements from the open sea) in August and October 1960. Based on measurements from these two months only, Sorokin $(1962,1964)$ provided APP estimates for the entire basin (109 and $112 \mathrm{~g} \mathrm{C} \mathrm{m}^{-2} \mathrm{yr}^{-1}$ for the two studies). Later, Sorokin (1982) revised his first APP estimates for the whole Black Sea to $220 \mathrm{~g} \mathrm{C} \mathrm{m}^{-2} \mathrm{yr}^{-1}$ after adding two additional data sets from September 1964 (Finenko, 1967) and August 1978 (Kondratyeva, 1979), despite the fact that the new PP data were similar to the values obtained in 1960. More recently, APP estimates for the different shelf regions and the open sea, obtained by integrating PP measurement, were based on data from an extended period (1960 - early/mid 1990s), but the methods of integration did not account for PP trends over time and decadal changes in trophic status were not resolved (Sorokin, 2002; Demidov, 2008). As a consequence, APP estimates were biased towards the more data-rich years during the peak eutrophication period.

Given the large difference among published APP estimates for the 1960s - 1970s (Sorokin, $1962 ; 1964 ; 1982)$ and general lack of PP measurements to describe the real seasonal variation for this period (Table 1), we used other proxy measurements (Chl $a$ and winter-early spring nitrate) to reconstruct PP seasonal variations in the early eutrophication period. Similarly, depth-integrated PP is commonly estimated from remote sensing of surface Chl $a$ concentrations by means of statistical relationships (e.g. Eppley et al., 1985; Smith and Baker, 1978). Such proxy PP estimates are particularly useful when applied to the regions for which they were derived (Berthelot and Deschamps, 1994; Mantyla et al., 1995; Vinogradov et al., 1999) and to annually averaged data (Harding et al., 2002; Iverson et al., 2000).

We found that the relationships between surface Chl $a$ concentration and depth-integrated PP were not significantly different for autumn, winter and spring, and that summer PP was generally higher relative to Chl $a$ (Fig. 3). These findings are supported by similar results from the open Black Sea (Yunev et al., 2002; Yunev, 2011), showing that relatively high PP was sustained despite low Chl $a$ concentrations. This seasonal change in the PP-Chl $a$ relationship is likely due to enhanced light conditions in summer, allowing phytoplankton cells to remain productive with a reduced amount of Chl $a$ (Vedernikov, 1976; 1978). Moreover, the phytoplankton community during this time of the year is dominated by small-size species with high affinity to inorganic nutrients, sustaining a high production (Chisholm, 1992). 


\subsection{APP during the early eutrophication phase}

APP estimates for the early eutrophication period can only be obtained by inference from other sources of information due to the lack of complete PP annual or seasonal information. For Region 2 Chl $a$ observations were used to proxy PP monthly means, whereas nitrate concentrations were used for the other shelf regions following the approach of Elmgren (1989). Elmgren (1989) estimated APP increases of $30-70 \%$ during the $20^{\text {th }}$ century in a coastal area of the northern Baltic proper, and showed that this result was consistent with estimates derived directly from Eppley and Peterson's (1979) relationship between "new" production and primary production. It should be noted, that the Eppley and Peterson's (1979) relationship was derived explicity for offshore areas, but Wassman (1986) has shown it may apply to coastal areas as well.

The Baltic Sea and Black Sea are both enclosed regional seas that have experienced eutrophication during the $20^{\text {th }}$ century, and since our APP calculations were derived on an approach developed for the Baltic Sea, we found it useful to compare these two systems. Our AIF values for the Black Sea shelf regions $(2.0-2.5)$ were higher than in the Baltic Sea $(1.3-1.7)$ due to larger increases in winter nitrate concentrations. This implies that the Black Sea has experienced a stronger nutrient enrichment than the Baltic Sea, which is also supported by studies of nitrogen inputs. Gustafsson et al. (2012) reported increases by factor 2-3 for nitrogen inputs to the Baltic Sea, whereas inorganic nitrogen inputs from the Danube River increased by factor 5 (Cociasu et al., 1996; Konovalov et al., 1999; Zaitsev et al., 2006). Moreover, Richardson and Heilmann (1995) compared historical ${ }^{14} \mathrm{C}$ PP measurements from the 1950 s made by Steemann Nielsen with PP monitoring data from the 1980s and found more than 2-fold increase in productivity for the Kattegat at the entrance to the Baltic Sea. For the same area, Carstensen et al. (2003) established significant links between nutrient inputs and productivity. Overall, these results suggest stronger nutrient enrichment and eutrophication in the Black Sea shelf region than in the coastal areas of the Baltic Sea.

It should be emphasized also that our APP values for the early eutrophication period (Fig. 7) differs from Sorokin's studies of the 1960s (Sorokin, 1962; 1964) and, in particular, the later study (Sorokin, 1982). These studies demonstrate too high APP values for 1960s - 1970s, that lead to an incorrect conclusion of no significant increase in PP from the 1960s to the late 1970-1980s (Sorokin, 2002). For similar reasons, Finenko et al. (2011) did not find any positive APP trends from 1950s to the beginning of the 2000s. At the same time, a number of studies in the Black Sea have reported long-term changes in phytoplankton biomass, including $\mathrm{Chl} a$, and nutrients, which can be used as supporting evidence of increasing productivity (Wasmund et al., 2001). 
For example, Romanian coastal waters (near Constanta) experienced increases from 1960s/1970s to 1980s/early 1990s in phytoplankton biomass from 2004 to $7143 \mathrm{mg} \mathrm{m}^{-3}$ and winter phosphate and nitrate concentrations from 0.34 to 6.54 and 1.60 to $6.90 \mu \mathrm{M}$, respectively (Bodeanu et al., 1998). Similarly, phytoplankton biomass increased from 347 to $4932 \mathrm{mg} \mathrm{m}^{-3}$ in the coastal waters of Bulgaria (Cape Galata) (Bodeanu et al., 1998). In Region 2 phytoplankton biomass increased during the same period from 550 to $3850 \mathrm{mg} \mathrm{m}^{-3}$ (Petranu et al., 1999), surface Chl $a$ from 0.66 to $9.0 \mathrm{mg} \mathrm{m}^{-3}$, winter-early spring phosphate and nitrate concentrations from 0.11 to 0.30 and 1.31 to $5.30 \mu \mathrm{M}$, respectively (Yunev et al., 2007). In the open Black Sea, averaged depthintegrated phytoplankton biomass increased from 3.3 to $19.6 \mathrm{~g} \mathrm{~m}^{-2}$ (Mikaelyan et al., 2013), summer Chl $a$ in the surface layer from 0.15 to $0.99 \mathrm{mg} \mathrm{m}^{-3}$ and in subsurface peak from 0.40 to $3.08 \mathrm{mg} \mathrm{m}^{-3}$, annual mean nitrates within the layer of depth maximum from 1.90 to $7.72 \mu \mathrm{M}$ (Yunev et al., 2002; 2005). This overwhelming evidence of changes during the second half of the $20^{\text {th }}$ century support an increased productivity in the Black Sea.

\subsection{Changes of the Black Sea trophic status}

Evaluation of trophic status changes is of special interest when aquatic ecosystems are subjected to eutrophication (Wasmund et al., 2001). According to Nixon (1995), eutrophication is defined as "an increase in the rate of supply of organic matter to an ecosystem". From this definition, it follows that eutrophication is a process and hence, it represents a change. Consequently, eutrophication does not equal the ecosystem trophic status. Secondly, the major point of concern is the change in the amount of organic matter (energy) that is available to support the metabolic demands of the ecosystem. Hence, eutrophication is the change in the ecosystem trophic status. Besides, Nixon (1995) noted that: 1) sources of organic carbon can either be fixation by primary producers (autochtonous carbon) and/or any input of organic matter from outside the system (allochthnous carbon) and 2) the greatest contribution to the increased organic carbon supply in most marine ecosystems during their eutrophication falls on the autochthonous organic carbon, i.e. on primary production.

Comparison of these two sources of organic carbon in the Black Sea (Table 5) confirms Nixon's presumption that the supply of autochthonous organic carbon exceeds land-based inputs by order of magnitude for both study periods, and most pronounced for the peak eutrophication period. Moreover, approximately $67 \%$ of autochthonous organic carbon in the Black Sea is produced in the open sea due to its substantially greater area, and only $11 \%$ and $23 \%$ come correspondingly from the more productive and the remaining shelf areas. Furthermore, the contribution of phytobenthos to 
407

408

409

410

411

412

413

414

415

416

417

418

419

420

total primary production in the Black Sea is unimportant. This assertion is based on estimates from the shallow lagoons in the Baltic Sea, where micro- and macrophytobenthos produced only $7 \%$ of the total primary production (Wasmund, 1986). In the Baltic Proper, Elmgren (1984) calculated the phytobenthos contribution to $3 \%$ of total primary production. Given that the Black Sea has a large deep area, where light cannot support phytobenthic production, the contribution of phytobenthos will be even less. Consequently, trophic status changes on the shelf and in the entire Black Sea can be assessed from the annual primary production of phytoplankton only.

\section{Table 5}

Comparison of the two major sources of organic carbon $\left(\mathrm{C}_{\text {org }}\right)$ in the Black Sea: fixation by primary producers (autochthonus carbon) within different regions and the entire basin, and riverine input of organic matter into the Black Sea (allochthonus carbon) during the early and peak eutrophication periods.

\begin{tabular}{|c|c|c|c|}
\hline \multirow[t]{2}{*}{ Source of organic carbon } & \multirow[t]{2}{*}{ Region square, $\mathrm{km}^{2} * * *$} & $\begin{array}{r}\mathrm{C} \\
10^{6} \mathrm{t}\end{array}$ & $\begin{array}{l}\text { rg., } \\
\text { C } \mathrm{yr}^{-1}\end{array}$ \\
\hline & & early & peak \\
\hline The most productive shelf (Regions $2+3$ ) & 21350 & 2.7 & 6.5 \\
\hline The remaining shelf (Regions $1,4-6$ ) & 89950 & 6.2 & 13.9 \\
\hline The open sea* & 305960 & 19.3 & 41.3 \\
\hline The whole Black Sea & 417260 & 28.2 & 61.7 \\
\hline Riverine input** & & 1.9 & 2.2 \\
\hline
\end{tabular}

421

422

423

424

425

426

427

428

429

430

431

432

(*) Data from (Yunev, 2011), (**) from (Zaitsev et al., 2006), (***) from (GEBCO, 2003).

APP estimates for the regions on the northwestern and western shelf varied substantially. Particularly, Region 1 influenced predominantly by the Dnieper, Dniester and Southern Bug rivers was less productive than Regions 2 and 3 influenced by the Danube River (Fig. 7). The enhanced productivity in Regions 2 and 3 can be explained by higher freshwater discharges and nutrient inputs (Cociasu et al., 1996; Konovalov et al., 1999; Zaitsev et al., 2006). The Danube River freshwater discharge $\left(\sim 210 \mathrm{~km}^{3} \mathrm{yr}^{-1}\right)$ substantially exceeds the collective stock from the Dnieper, Dniester and Southern Bug rivers $\left(\sim 63 \mathrm{~km}^{3} \mathrm{yr}^{-1}\right)$, and inputs of inorganic nitrogen and phosphorus are 4-8 times higher from the Danube River (Table 6) yielding overall higher nutrient concentrations with Danube waters. 
433

434

435

436

438

439

440

441

442

443

444

445

446

447

448

449

450

451

452

453

454

455

456

457

458

459

460

Table 6

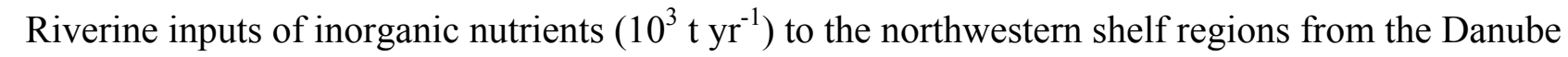
River and Dnieper, Dniester, and Southern Bug rivers (DDSB) during two different periods (Cociasu et al., 1996; Konovalov et al., 1999; Zaitsev et al., 2006).

\begin{tabular}{lcccc}
\hline \multirow{2}{*}{ Nutrient } & \multicolumn{2}{c}{$1950-1960$} & \multicolumn{2}{c}{$1980-1990$} \\
\cline { 2 - 5 } & Danube & DDSB & Danube & DDSB \\
\hline Inorganic N & 141.8 & 33.84 & 756.0 & 110.3 \\
Phosphate & 12.7 & 2.35 & 39.6 & 4.98 \\
Silicate & 785.0 & 188.7 & 252 & 77.1 \\
\hline
\end{tabular}

Since the mid-1990s APP (estimated from Chl $a$ measurements) in the open Black Sea has decreased approximately 15-20\% (Yunev, 2011). The main reason for this oligotrophication (Nixon, 2009) was the reduction of riverine nutrients inputs to the Black Sea caused by the decline of industrial activities in Eastern Europe and marked decrease in fertilizers and P-containing detergents use during the economic recession between 1989 and 1994 (Ragueneau et al., 2002). Unfortunately, more recent estimates of APP from the shelf region are not available due to lack of PP and Chl a measurements. However, other indicators of eutrophication suggest reduced productivity in the shelf region as well. Winter nutrient concentrations in the surface layer declined during the late 1990s (Cociasu and Popa, 2005) and changes in summer oxygen concentration above (decrease) and below (increase) the seasonal thermocline in the mid-1990s (Yunev et al., 2007) suggests a reduced photosynthetic activity. Thus, it is likely that the shelf region has experienced a similar decrease in APP as observed for the open Black Sea.

\section{Conclusions}

The large increase in nutrient inputs to the Black Sea, particularly from the Danube River, has stimulated eutrophication in the shelf region. APP estimates for the major part of the shelf region document a change from oligotrophy (64-89 $\left.\mathrm{g} \mathrm{C} \mathrm{m}^{-2} \mathrm{yr}^{-1}\right)$ in the early eutrophication phase (19631976) to mesotrophy (138-190 $\left.\mathrm{g} \mathrm{C} \mathrm{m}^{-2} \mathrm{yr}^{-1}\right)$ during the peak eutrophication phase (1985-1992), whereas the shallow shelf waters $(<50 \mathrm{~m})$ off the Romanian and Bulgarian coasts experienced a change from mesotrophic (125-127 $\mathrm{g} \mathrm{C} \mathrm{m}^{-2} \mathrm{yr}^{-1}$ ) to eutrophic (266-318 $\mathrm{g} \mathrm{C} \mathrm{m}^{-2} \mathrm{yr}^{-1}$ ) conditions. Overall, the trophic level of the entire Black Sea changed from oligotrophic $\left(\sim 68 \mathrm{~g} \mathrm{C} \mathrm{m}^{-2} \mathrm{yr}^{-1}\right)$ to mesotrophic $\left(\sim 148 \mathrm{~g} \mathrm{C} \mathrm{m}^{-2} \mathrm{yr}^{-1}\right)$ during the second half of the $20^{\text {th }}$ century. 
462

463

464

465

466

467

468

469

470

471

472

473

474

475

476

477

478

479

480

481

482

483

484

485

486

487

488

489

490

491

492

493

494

495

496

497

\section{Acknowledgements}

This study would not have been conducted without the support of the PERSEUS project (FP7 287600), HBS project (www.bs-hotspots.eu) and DEVOTES project (ENV.2012.6.2-3) funded by the European Commission research programs.

\section{References}

Aubrey, D., Moncheva, S., Demirov, E., Diaconu, V., Dimitrov, A., 1996. Environmental changes in the western Black Sea related to anthropogenic and natural conditions. Journal of Marine Systems 7, 411-425.

Berthelot, B., Deschamps, P.-Y., 1994. Evaluation of bio-optical algorithms to remotely sense marine primary production from space. Journal of Geophysical Research 99, 7979-7989.

Bodeanu, N., Moncheva, S., Ruta, G., Popa, L., 1998. Long-term evolution of the algal blooms in Romanian and Bulgarian Black Sea waters. Cercetari marine. IRCM Constanta 31, 37-55.

Bologa, A.S., 1977. The phytoplanktonic assimilatory pigments along the Romanian coast of the Black Sea during 1976. Cercetari marine. IRCM Constanta 10, 95-107.

Carstensen, J., Conley D.J., Müller-Karulis, B., 2003. Spatial and temporal resolution of carbon fluxes in a shallow coastal ecosystem, the Kattegat. Marine Ecology Progress Series 252, 35-50.

Chisholm, S.W., 1992. Phytoplankton size. In: Falkowski, P.G., Woodhead A.D. (Eds.), Primary Productivity and Biogeochemical Cycles in the Sea, Plenum Press, New York, pp. 213-237.

Cociasu, A., Dorogan, L., Humborg, C., Popa, L., 1996. Long-term ecological changes in Romanian coastal waters of the Black Sea. Marine Pollution Bulletin 32, 32-38.

Cociasu, A., Popa, L., 2005. Significant changes in Danube nutrient loads and their impact on the Romanian Black Sea coastal waters. Cercetari marine. IRCM Constanta 35, 25-37.

Demidov, A.B., 2008. Seasonal variability and assessment of annual primary production of the Black Sea phytoplankton. Oceanology 48, 718-733 (in Russian).

Elmgren, R. 1984. Trophic dynamics in the enclosed, brackish Baltic Sea. Rapports et Proce`s-verbeaux des Re'unions, Conseilinternational pour l'Exploration de la Mer 183, 152-169.

Elmgren, R., 1989. Man's impact on the ecosystem of the Baltic Sea: energy flows today and at the turn of the century. Ambio 18, 326-332.

Eppley, R.W., Peterson, B.J., 1979. Particulate organic matter flux and planktonic new production in the deep ocean. Nature 282, 677-680.

Eppley, R.W., Steward, E., Abbott, M.R., Heyman, U., 1985. Estimating ocean primary production from satellite chlorophyll: Introduction to regional differences and statistics for the Southern California Bight. Journal of Plankton Research 7, 57-70. 
Finenko, Z.Z., 1967. Primary production in the South Seas/Questions of biooceanography. Naukova Dumka, Kiev, pp. 69-74 (in Russian).

Finenko, Z.Z., 1979. Phytoplankton production. In: Kovalev, A.V., Finenko, Z.Z. (Eds.), Foundations of biological productivity of the Black Sea. Naukova Dumka, Kiev, pp. 88-99 (in Russian).

Finenko, Z.Z., Churiliva, T.Y., Suslin, V.V., 2009. The regional model to calculate the Black Sea primary production using satellite color scanner SeaWiFS. Marine Ecological Journal 8, 81-106 (in Russian).

Friedrich, J., Dinkel C., Friedl, G., Pimenov, N., Wijsman, J., Gomoiu, M.T., Cociasu, A., Popa, L., Wehrli, B., 2002. Benthic nutrient cycling and diagenetic pathways in the north-western Black Sea. Estuarine, Coastal and Shelf Science 54, 369-383.

GEBCO, 2003. The GEBCO Digital Atlas UNESCO - BODC (British Oceanographic Data Centre): International Hydrographic Organisation (IHO) and Intergovernmental Oceanographic Commission (IOC). http://www.bodc.ac.uk/cgi-bin/framer\%3Fhttp\% 3A//www.bodc.ac.uk/projects/ gebco/.

Gustafsson, B.G., Schenk, F., Blenckner, T., Eilola, K., Meier, H.E.M., Müller-Karulis, B., Neumann, T., Ruoho-Airola, T., Savchuk, O., Zorita, E., 2012. Reconstructing the development of Baltic Sea eutrophication 1850-2006. Ambio 41, 534-548.

Harding, L.W., Jr., Mallonee, M.E., Perry, E.S., 2002. Toward a predictive understanding of primary productivity in temperate, partially stratified estuary. Estuarine, Coastal and Shelf Science 55, 437 463.

Humborg, C., 1997. Primary productivity regime and nutrient removal in the Danube estuary. Estuarine, Coastal and Shelf Science 45, 579-589.

Ivanov, L., Konovalov, S., Melnikov, V., Mikaelyan, A., Yunev, O., Basturk, O., Belokopytov, V., Besiltepe, S., Bodeanu, N., Bologa, A., Cociasu, A., Diakonu, V., Kamburska, L., Kideys, A., Mankovsky, V., Moncheva, S., Nezlin, N., Niermann, U., Petranu, A., Shalovenkov, N., Shuskina, E., Salihoglu, I., Senichkina, L., Uysal, Z., Vedernikov, V., Yakubenko, V., Yakushev, E., Yilmaz, A., 1998. Physical, chemical and biological data sets of the TU Black Sea Data Base: description and evaluation. In: Ivanov, L., Oguz, T. (Eds.), Ecosystem modeling as a management tool for the Black Sea, Vol. 1. Kluwer Academic Publishers, Dordrecht, pp. 11-37.

Iverson, R.L., Esaias, W.E., Turpie, K., 2000. Ocean annual phytoplankton carbon and new production, and annual export production estimated with empirical equations and CZCS data. Global Change Biology, 6, $57-72$.

Kondratyeva, T.M., 1979. Phytoplankton primary production of the Black Sea. Complex investigations of the Black Sea. Marine Hydrophysical Institute AS USSR, Sevastopol, pp. 151-161(in Russian).

Konovalov, S.K., Ivanov, L.I., Murray, J.W., Eremeeva, L.V., 1999. Eutrophication: a plausible cause for changes in hydrochemical structure of the Black Sea anoxic layer. In: Besiktepe, S.T., Unluata, U., Bologa, A.S. (Eds.), Environmental Degradation of the Black Sea: Challenges and Remedies. Kluwer Academic Publishers, Dordrecht, pp. 61-74. 
535

536

537

538

539

540

541

542

543

544

545

546

547

548

549

550

551

552

553

554

555

556

557

558

559

560

561

562

563

564

565

566

567

568

569

Konovalov, S.K., Murray, J.W., 2001. Variations in the chemistry of the Black Sea on a time scale of decades (1960-1995). Journal of Marine Systems 31, 217-243.

Kopelevich, O.V., Sheberstov, S.V., Yunev, O.A., Basturk, O., Finenko, Z.Z., Nikonov, S., Vedernikov, V.I., 2002. Surface chlorophyll in the Black Sea over 1978-1986 derived from satellite and in situ data. Journal of Marine Systems 36, 145-160.

Larsson, U., 1986. The Baltic Sea. In: Rosenberg, R. (Ed.), Eutrophication of waters surrounding Sweden. National Swedish Environment Protection Board, Report 3054, pp. 16-70.

McQuatters-Gollop, A., Gilbert, A.J., Mee, L.D., Vermaat, J.E., Artioli, Y., Humborg, C., Fred Wulff, F., 2009. How well do ecosystem indicators communicate the effects of anthropogenic eutrophication? Estuarine, Coastal and Shelf Science 82, 583-596.

Mantyla, A.W., Venrick, E.L., Hayward, T.L., 1995. Primary production and chlorophyll relationship, derived from ten years of CalCOFI measurements. CalCOFI Report 36, 159-166.

Mee, L., 1992. The Black Sea in crisis: call for concerned international action. Ambio 21, 278-286.

Mikaelyan, A.S., Zatsepin, A.G., Chasovnikov, V.K., 2013. Long-term changes in nutrient supply of phytoplankton growth in the Black Sea. Journal of Marine Systems 117-118, 53-64.

Moncheva, S., Petrova-Karadjova, V., Palazov, A., 1995. Harmful algal blooms along Bulgarian Black Sea coast and possible patterns of fish and zoobenthic mortalities. Harmful Marine Algal Blooms: Proceedings of the Sixth International Conference on Toxic Marine Phytoplankton, Paris, pp. 193-198.

Nehring, D., Ærtebjerg, G., Alenius, P., Astok, V., Fonselius, S., Hannus, M., Tervo, V., Troszinska, A., Tulkki, P., Yurkovskis, A.K., 1987. In: Lassing, J. (Ed.), First Periodic Assessment of the State of the Marine Environment of the Baltic Sea Area, 1980-1985; Background Document. Baltic Sea Environment Proceedings 17B, pp. 35-81.

Nixon, S.W., 1995. Coastal marine eutrophication: a definition, social causes, and future concerns. Ophelia 41, 199-219.

Nixon, S.W., 2009. Eutrophication and the macroscope. Hidrobiologia 659, 5-19.

Oguz, T., Latun, V.S., Latif, M.A., Vladimirov, V.V., Sur, H.I., Markov, A.A., Ozsoy, E., Kotovshchikov, V.V., Eremeev, V.N., Unluata, U., 1993. Circulation in the surface and intermediate layers of the Black Sea. Deep-Sea Research 40, 1597-1612.

Parhomenko, A.W., Krivenko, O.W., 2011. Estimation of phytoplankton biomass in the Black Sea for the period 1948 - 2001. In: Eremeev, V.N., Gaevskaya, A.V., Shulman G.E., Zagorodnyaya Ju.A. (Eds.), Biological resources of the Black Sea and Sea of Azov. Institute of Biology of the Southern Seas NAS of Ukraine, EKOSI-Gidrofizika, Sevastopol, pp. 237-249 (in Russian).

Petranu, A., Apas, M., Bodeanu, N., Bologa, A.S., Dumitrache, C., Moldoveanu, M., Radu, G., Tiganus, V., 1999. Status and evolution of the Romanian Black Sea coastal ecosystem. In: Besiktepe, S.T., 
Unluata, U., Bologa, A.S. (Eds.), Environmental Degradation of the Black Sea: Challenges and Remedies. Kluwer Academic Publishers, Dordrecht, pp. 175-195.

Ragueneau, O., Lancelot, C., Egorov, V., Verlimmeren, J., Cociasu, A., Deliat, G., Krastev, A., Daoud, N., Rousseau, V., Popovitchev, V., Brion, N., Popa, L., Cauwet, G., 2002. Biogeochemical transformations of inorganic nutrients in the mixing zone between the Danube River and the northwestern Black Sea. Estuarine, Coastal and Shelf Science 54, 321-336.

Richardson, K., Heilmann, J.P., 1995. Primary production in the Kattegat past and present. Ophelia 41, $317-328$.

Rozhdestwenskiy, A., 1990. On long-year dynamics of the most important hydrochemical indices in the Bulgarian part of the Black Sea. Oceanology, BAS, Sofia 1, 9-18.

Skolka, H.V., 1968. Les pigments assimilateurs du phytoplankton du littoral roumain de la mer Noire. Rapporteur Communication International du Mer Meditteranee 19, 567-570.

Smith, R.C., Baker, K.S., 1981. Optical properties of the clearest natural waters (200-800 nm). Applied Optics 20, 177- 184.

Sorokin, Y.I., 1962. Photosynthesis production of phytoplankton in the Black Sea. Reports of the Academy of Sciences of the USSR 144, 914-917 (in Russian).

Sorokin, Y.I., 1964. Production of photosynthesis of phytoplankton in the Black Sea. Proceedings of the Academy of Sciences of the USSR 5, 749-759 (in Russian).

Sorokin, Y.I., 1982. The Black Sea. Nauka, Moscow, 217 p. (in Russian).

Sorokin, Y.I., 2002. The Black Sea. Ecology and Oceanography. Backhuys Publishers, Leiden, 875 p.

Stelmakh, L.V., Yunev, O.A., Finenko, Z.Z. Vedernikov, V.I., Bologa, A.S., Churilova, T.Yu., 1998. Peculiarities of seasonal variability of primary production in the Black Sea. In: Ivanov, L., Oguz, T. (Eds.), Ecosystem modeling as a management tool for the Black Sea, Vol. 1. Kluwer Academic Publishers, Dordrecht, pp. 93-104.

Sur, H., Ozsoy, E., Ilyin, Y.P., Unluata, U., 1996. Coastal/deep interactions in the Black Sea and their ecological/environmental impacts. Journal of Marine Systems 7, 293-320.

TU Black Sea Data Base, 2003. Supplied with Ocean Base 3.07 DBMS/NATO SfP-971818 ODBMS Black Sea Project, July 15 2003. CD for Windows NT, 98, 2000, Me, XP.

Unluata, U., Aubrey, D.G., Belberov, Z. et al., 1993. International Program Investigates the Black Sea. Eos, Transactions, American Geophysical Union 74, pp. 401/407/412.

Vedernikov, V.I., 1976. Influence of environmental factors on the assimilation number in natural populations of marine phytoplankton. Proceedings of Institute of Oceanology of AS USSR 105, 106129 (in Russian).

Vedernikov, V.I., 1978. Seasonal changes in the assimilation number of marine phytoplankton. Proceedings of All-Russian Hydrobiological Society 22, 18-31(in Russian). 
605

606

607

608

609

610

611

612

613

614

615

616

617

618

619

620

621

622

623

624

625

626

627

628

629

630

631

632

633

634

635

636

637

638

639

Vedernikov, V.I., Demidov, A.B., 1993. Primary production and chlorophyll in the deep regions of the Black Sea. Oceanology 33, 229-235 (in Russian).

Vedernikov, V.I., Demidov, A.B., 2002. Long-term and seasonal variability of chlorophyll and primary production in the eastern regions of the Black Sea. In: Zatsepin, A.G., Flint, M.V. (Eds.), Multidisciplinary investigations of the northeast part of the Black Sea. Nauka, Moscow, pp. 212-234 (in Russian).

Velikova, V., 1998. Long-term study of red tides in the Western part of the Black Sea and their ecological modeling. In: Reguera, B., Blanco, J., Fernández, M.L., Wyatt, T. (Eds), Harmful Algae. Proceedings of the 8th International Conference on Harmful Algae, Xunta de Galicia and Intergovernmental Oceanographic Commission of UNESCO: Paris, 261-265.

Velikova, V., Moncheva, S., Petrova, D., 1999. Phytoplankton dynamics and red tides (1987-1997) in the Bulgarian Black Sea. Journal of Water Science and Technology 39, 27-36.

Vinogradov, M.E., Shushkina, E.A., Nezlin, N.P., Vedernikov V.I., Gagarin V.I., 1999. Correlation between different parameters of the ecosystem of the epipelagic zone of the World Ocean. Oceanology 39, 54-63.

Vladimirov, V.L., Mankovsky, V.I., Solovev, M.V., Mishonov, A.V., 1997. Seasonal and long-term variability of the Black Sea optical parameters. In: Ozsoy, E., Mikaelyan, A. (Eds.), Sensitivity to Change: Black Sea, Baltic Sea and North Sea. Kluwer Academic Publishers, Dordrecht, pp. 33-48.

Wasmund, N., 1986. Ecology and bioproduction in the microphytobenthos of the chain of shallow inlets (Boddens) south of the Darss-Zingst peninsula (Southern Baltic Sea). Internationale Revue der gesamten Hydrobiologie 71, 153-178.

Wasmund, N., Andrushatis, A., Lysiak-Pastuszak, E., Müller-Karulis, B., Nausch, G., Neumann, T., Ojaveer, H., Olenina, I., Postel, L., Witek, Z., 2001. Trophic status of the south-eastern Baltic Sea: a comparison of coastal and open areas. Estuarine, Coastal and Shelf Science 53, 849-864.

Wassmann, P., 1986. Benthic nutrient regeneration as related to primary production in the westNorwegian coastal zone. Ophelia 26, 443-456.

Yimaz, A., Yunev, O.A., Vedernikov, V.I., Moncheva, S., Bologa, A.S., Cociasu, A., Ediger, D., 1998. Unusual temporal variations in the spatial distribution of chlorophyll-a in the Black Sea during 19901996. In: Ivanov, L., Oguz, T. (Eds.), Ecosystem modeling as a management tool for the Black Sea, Vol. 1. Kluwer Academic Publishers, Dordrecht, pp. 105-120.

Yunev, O.A., 2011. Eutrophication and annual primary production of phytoplankton in the deep-water part of the Black Sea. Oceanology 51, 616-625.

Yunev, O.A., Carstensen, J., Moncheva, S., Khaliulin, A., Ærtebjerg, G., Nixon, S. 2007. Nutrient and phytoplankton trends on the western Black Sea shelf in response to cultural eutrophication and climate changes. Estuarine, Coastal and Shelf Science 74, 63-76. 
640 Yunev, O.A., Moncheva, S., Carstensen, J., 2005. Long-term variability of vertical chlorophyll a and nitrate profiles in the open Black Sea: eutrophication and climate change. Marine Ecology Progress Series 294, 95-107.

Yunev, O.A., Shulman, G.E., Yuneva, T.V., Moncheva, S., 2009. Relationship between the Abundance of Small Pelagic Fishes and the Phytoplankton Biomass as an Indicator of the State of the Pelagic Ecosystem of the Black Sea. Doklady Biological Sciences 428, 454- 457. 2002. Long-term variations of surface chlorophyll $a$ and primary production in the open Black Sea. Marine Ecology Progress Series 230, 11-28. Sea: Biology and Ecology. Naukova Dumka, Kiev, 701 p. (in Russian).

651

652 